\title{
Burdens of PBBs, PBDEs, and PCBs in tissues of the cancer patients in the e-waste disassembly sites in Zhejiang, China
}

\author{
Gaofeng Zhao ${ }^{\mathrm{a}, \mathrm{b}}$, Zijian Wang ${ }^{\mathrm{a}, *}$, Huaidong Zhou ${ }^{\mathrm{b}}$, Qing Zhao ${ }^{\mathrm{c}}$ \\ a State Key Laboratory of Environmental Aquatic Chemistry, Research Center for Eco-Environmental Sciences, Chinese Academy of Sciences, Beijing, 100085, China \\ ${ }^{\mathrm{b}}$ Department of Water Environment, China Institute of Water Resources and Hydro-power Research, Beijing, 100038, China \\ ${ }^{c}$ Environmental Monitoring Station, Jiulongpo District, Chongqing, China
}

\section{A R T I C L E I N F O}

\section{Article history:}

Received 10 November 2008

Received in revised form 14 May 2009

Accepted 20 May 2009

Available online 17 June 2009

\section{Keywords:}

Body burden

PBBs

PBDES

PCBs

E-waste

\begin{abstract}
A B S T R A C T
This study was conducted to explore the burdens of PBBs, PBDEs, and PCBs among cancer patients living in the e-waste disassembly sites. The contents of 23 PBB congeners, 12 PBDE congeners, and 27 PCB congeners in kidney, liver, and lung samples were measured by GC-MS. The results showed that low-brominated PBBs and PBB153 were the predominant congeners. PBDE47 were the most predominant PBDE congeners. PBDE209 were detected in $>70 \%$ of the samples, with geometric means ranging from 64.2 to $113.9 \mathrm{ng} \mathrm{g}^{-1}$ lipid. Among the three subfamilies of PHAHs, PCB concentrations were the highest. The detected levels of PHAHs were in the same order of magnitude in the three tissues, which indicated that any of the three tissues could be the suitable indicator for assessing body burdens of PHAHs. PBB contents (181-192 $\mathrm{ng} \mathrm{g}^{-1}$ lipid) were obviously higher than those reported in the general USA population ( $3-8 \mathrm{ng} \mathrm{g}^{-1}$ lipid). PBDE levels (174.1-182.3 $\mathrm{ng} \mathrm{g}^{-1}$ lipid) were comparable to those reported in the USA population, but significantly higher than those of the European population. PCBs levels were comparable to those of the European population. The high cancer incidence in the disassembly sites may be related to higher burdens of PBBs, PBDEs, and PCBs in tissues.
\end{abstract}

(c) 2009 Elsevier B.V. All rights reserved.

\section{Introduction}

Waste electrical and electronic equipment, or "e-waste" for short, has become the fastest growing stream of all solid waste found in China in that huge amounts of such waste are constantly being generated from (legal or illegal) imports and domestic use (Hicks et al., 2005). A cluster of small villages in the littoral zone in the Zhejiang province has become a booming recycling center for e-waste, but nonetheless at the expense of having thousands of village workers engaged in primitive recycling operations without the use of adequate protective equipment (Zhao et al., 2008). Such primitive operations include, but are not limited to, stripping of metals in open pit acid baths, removing electronic components from circuit boards by heating over a grill, and recovering metals by burning cables in (or near) the cropland (Deng et al., 2007). Yet as a result of these operations and through leakage, evaporation, runoff, and leaching, many toxic chemicals, such as polybrominated biphenyls (PBBs), polybrominated diphenyl ethers (PBDEs) and polychlorinated biphenyls (PCBs), have been reported to be released into the local environmental and human matrices such as air (Deng et al., 2007), sediment (Wang et al., 2005; Luo et al., 2007), soil ( Liu et al., 2006; Zhao et al., 2008), cord blood (Qu et al., 2007), and milk ( Zhao et al., 2007a). These pollutants can

\footnotetext{
* Corresponding author. Tel.: +8610 62849107; fax: +861062849140. E-mail address: wangzj@rcees.ac.cn (Z. Wang).
}

be bioaccumulated in the aquatic and the terrestrial food chains and biomagnified in humans via food due to their lipophilicity (Zhao et al., 2007a,b). These earlier findings suggest that the residents living near the e-waste disassembly site might be at high health risk.

Polyhalogenated aromatic hydrocarbons (PHAHs) represent a large family of highly lipophilic and environmentally persistent substances, of which PBBs, PBDEs, and PCBs are three subfamilies that were of great concern in the present study. All three PHAHs subfamilies are notably toxic and bioaccumulative (Hardy, 2000; McDonald, 2002). Animal studies ( WHO, 1994a,b) showed that the PHAHs in these three subfamilies not only were they capable of disrupting endocrine functions but could also induce carcinogenicity.

An increasing incidence of cancer (such as liver cancer, and lung cancer) has been found around the e-waste disassembly sites during the last decades. However, there is still no report on body burdens of PHAHs among these local cancer patients in the disassembly sites. Accordingly, the present study had its focus on assessing body burden (or internal exposure) of local cancer patients to the 62 PHAHs that were deemed likely present in e-waste. Human tissue samples can reflect steady-state concentrations of lipophilic chemicals, which is considered as a suitable indicator for the study of environmental or occupational exposure to many chemical pollutants including PBDEs and PCBs (Meironyté Guvenius et al., 2001; Petreas et al., 2004; Johnson-Restrepo et al., 2005; Naert et al., 2006; Covaci et al., 2008). Therefore, tissue samples (kidney, liver, and lung) were collected for 
assessing body burdens of PHAHs. This exploration represented the first of its kind in reporting extensively the recent levels of PBBs, PBDEs, and PCBs in tissues of local cancer patients. Information obtained from this type of exploration may also be useful for subsequent evaluation of the health risks at issue.

\section{Materials and methods}

\subsection{Sample collection and storage}

After obtained consent from participants according to procedures approved by the Ethics Committees of Research Center for EcoEnvironmental Sciences, Chinese Academy of Sciences, kidney $(n=19)$, liver $(n=55)$, and lung $(n=7)$ tissue samples (each of 10-50 g) were collected from these surgical patients who were newly diagnosed for cancer from April 2007 to January 2008 at the First Hospital of Wenling and the Second Hospital of Wenling, with each sample placed into a separate chemically-cleaned glass bottle, and labeled with a unique code and the proper sampling date. The mean age of the individuals was 65 years ranging from 32 to 94 years. All samples were transported to the analytical laboratory as soon as possible in ice boxes and continued to be stored in the dark at $-20{ }^{\circ} \mathrm{C}$ until analysis.

\subsection{Materials and chemicals}

The following standards were obtained from the Cambridge Isotope Laboratory (USA): 12 native PBDE congeners; $7{ }^{13} \mathrm{C}_{12}$-labeled PBDEs (PBDE15, 28, 47, 99, 153, 154, and 183); 23 PBB congeners; 27 PCB congeners; and surrogate standards pentachloro-nitrobenzene (PCNB), 2,4,5,6-tetrachloro-m-xylene (TMX), and PCB209. All solvents used (hexane, acetone, and methylene chloride) were of pesticide grade (Promochem, Germany). Silica gel (100-200 mesh) was purchased from Promochem (Germany). Aluminum foil was rinsed with acetone and dried at ambient temperature prior to use. Sodium sulfate (granular, anhydrous) was pre-cleaned with methylene chloride and purified by heating at $450{ }^{\circ} \mathrm{C}$ for $8 \mathrm{~h}$ in a shallow metallic enamel tray. Cellulose extraction thimbles of $33 \mathrm{~mm}$ i.d. and $94 \mathrm{~mm}$ in length were from Schleicher \& Schuell (Germany); these thimbles were pre-cleaned by Soxhlet extraction with $n$-hexane: acetone $(3: 1, \mathrm{v} / \mathrm{v})$ for $4 \mathrm{~h}$ before use. Glassware was soaked, cleaned with chromic solution, rinsed thoroughly with distilled water and acetone, and finally heated in a baking oven (Heraeus, Germany) at temperatures programmed from $40^{\circ} \mathrm{C}$ to $420^{\circ} \mathrm{C}$ at a rate of $15^{\circ} \mathrm{C} \mathrm{min}-1$ for $16 \mathrm{~h}$.

\subsection{Sample preparation and clean-up}

The tissue samples were first individually pulverized by a stainlesssteel machine, then, were all freeze-dried. About 2-5 g of these dried tissue residues from each sample was introduced into a pre-cleaned thimble and Soxhlet extracted for $24 \mathrm{~h}$ using $180 \mathrm{~mL} n$-hexane/ acetone $(3: 1, v / v)$ solution. For this preparation process, TMX, PCNB, and PCB209 were added to each sample as surrogate congener standards. The extract from each sample was then concentrated to about $1 \mathrm{~mL}$ by rotary evaporation (550 mbar, $60{ }^{\circ} \mathrm{C}$ ). After gravimetrical lipid determination, the concentrated extracts were further cleaned individually by a multilayer silica gel column containing: $2 \mathrm{~g}$ of anhydrous sodium sulfate; $8 \mathrm{~g}$ of silver nitrate $\left(\mathrm{AgNO}_{3}\right)$ silica $\left(10 \%, \mathrm{AgNO}_{3} \mathrm{w} / \mathrm{w}\right) ; 2 \mathrm{~g}$ of deactivated silica $(3.3 \%$ organic-free reagent water $\mathrm{w} / \mathrm{w}$ ); $15 \mathrm{~g}$ of acidic silica (44\% conc. sulphuric acid $\mathrm{w} / \mathrm{w}$ ); $1 \mathrm{~g}$ of deactivated silica (3.3\% organic-free reagent water $\mathrm{w} / \mathrm{w}$ ); and $2 \mathrm{~g}$ of anhydrous sodium sulfate. The silica gel column was wrapped in aluminum foil throughout clean up, to protect samples from debromination induced from UV-light, and preeluted with $80 \mathrm{~mL}$ of hexane prior to adding to the extract. The first fraction eluted with $n$-hexane $(100 \mathrm{~mL}$ ) was used to concentrate the PCB congeners, with the second fraction (eluted with $10 \%$ methylene chloride in $80 \mathrm{ml} n$-hexane) intended for collection of the PBB and PBDE congeners (US EPA, 1996). The eluants were concentrated separately to about $1 \mathrm{~mL}$, again by rotary evaporation. The solvent of each sample was evaporated to dryness by gentle nitrogen stream at $25{ }^{\circ} \mathrm{C}$ and redissolved in $200 \mu \mathrm{L}$ hexane.

\subsection{Chemical analysis}

The chemical analysis was performed using an Agilent 5975 GCMS system equipped with a capillary DB-5MS column (5\% phenyl $/ 95 \%$ methyl silicone, $30 \mathrm{~m}, 0.25 \mathrm{~mm}$ i.d., and $0.25 \mu \mathrm{m}$ film thickness, from J\&W Scientific, Folsom, California, USA). The column oven temperature was programmed from $90{ }^{\circ} \mathrm{C}$ (initial time, $1 \mathrm{~min}$ ) to $250{ }^{\circ} \mathrm{C}$ at a rate of $4{ }^{\circ} \mathrm{C} \mathrm{min}-1$, then from $250{ }^{\circ} \mathrm{C}$ to $300{ }^{\circ} \mathrm{C}$ at a rate of $25^{\circ} \mathrm{C} \mathrm{min}^{-1}$, and held for $5 \mathrm{~min}$. The GC injector temperature was maintained at $260{ }^{\circ} \mathrm{C}$, with the temperatures of the MS ion source and of the transfer line being kept at $230{ }^{\circ} \mathrm{C}$ and $300{ }^{\circ} \mathrm{C}$, respectively. The carrier gas was helium at a constant flow rate of $1.5 \mathrm{~mL} \mathrm{~min}^{-1}$. The mass spectrometer was operated in the electron impact (EI) ionization mode with an electron energy of $70 \mathrm{eV}$. Samples $(1 \mu \mathrm{l})$ were injected in the splitless mode with a solvent delay set at $4 \mathrm{~min}$. The molecular ions $\left([\mathrm{M}]^{+}\right.$or $\left.[\mathrm{M}+2]^{+}\right)$and the fragment ions resulting from the loss of $\mathrm{X}_{2}$ (i.e., $\left[\mathrm{M}-\mathrm{X}_{2}+2\right]^{+}$or $\left[\mathrm{M}-\mathrm{X}_{2}+4\right]^{+}$, where $\mathrm{X}=$ chlorine or bromine) were selected as the precursor ions for mass spectrometric analysis. Quantitative analyses of PBB209 and PBDE209 were performed on the Agilent 5975 GC-MS equipped with a DB-5MS (5\% phenyl/95\% methyl silicone, $15 \mathrm{~m}, 0.25 \mathrm{~mm}$ i.d., and $0.1 \mu \mathrm{m}$ film thickness, from J\&W Scientific, Folsom, California, USA), at temperatures programmed from $90^{\circ} \mathrm{C}$ (initial time, $1 \mathrm{~min}$ ) to $250^{\circ} \mathrm{C}$ at a rate of $10{ }^{\circ} \mathrm{C} \min ^{-1}$, then from $250{ }^{\circ} \mathrm{C}$ to $300{ }^{\circ} \mathrm{C}$ at $15{ }^{\circ} \mathrm{C} \mathrm{min}{ }^{-1}$, and finally held for $8 \mathrm{~min}$. Mass spectrometer condition was performed by $\mathrm{EI}$ ( $70 \mathrm{eV}$ ) and selected ion monitoring of high abundance ( $\mathrm{m} / \mathrm{z} 943$ and $\mathrm{m} / \mathrm{z} 799$ for PBB209 and PBDE209, respectively).

\subsection{Quality assurance/quality control}

For every batch of 10 samples, a solvent blank and a procedural blank were added to ensure that the samples and the analysis process were free of contamination. The detection limits (LOD) of the targeted compounds were defined as 3 times the signal to noise $(\mathrm{S} / \mathrm{N})$ ratio, ranged from 0.08 to $0.24 \mathrm{ng} \mathrm{g}^{-1}$ lipid for PBB congeners, from 0.08 to $0.32 \mathrm{ng} \mathrm{g}^{-1}$ lipid for PBDE congeners, from 0.02 to $0.12 \mathrm{ng} \mathrm{g}^{-1}$ lipid for PCB congeners, and from 0.80 to $1 \mathrm{ng} \mathrm{g}^{-1}$ lipid for PBB209 and PBDE209. Spike recoveries for ${ }^{13} \mathrm{C}_{12}$-labeled PBDEs (at $10 \mathrm{ng}$ ) ranged from 75.2 to $96.5 \%$; and those for TMX, PCNB, and PCB209 ranged from 70.4 to $92.5 \%, 81.6$ to $107.4 \%$, and 90.8 to $112.6 \%$, respectively. Triplicate analysis of six diluted standard solutions (1.0, 5.0, 10.0, 25.0, 50.0, and $100.0 \mathrm{ng} \mathrm{mL} \mathrm{mL}^{-1}$ ) was performed for each selected standard mixture. Multi-level calibration curves were constructed for the quantification; and good to excellent linearity $\left(r^{2}>0.99\right)$ was achieved.

\subsection{Data analysis}

A value of half LOD was given to the samples in which the contents of PBBs, PBDEs or PCBs were not detectable. Descriptive statistics (mean, range, etc.) were computed to characterize the concentrations of PBBs, PBDEs, and PCBs in the samples. All statistical analyses were performed for congeners for which more than $50 \%$ of the samples were above the LOD, using the Statistical Package for the Social Sciences (SPSS for Windows ver. 11.5) where applicable. The (statistical) term mean used throughout this paper referred to geometric mean. The levels of PBB209 and PBDE209, though measured and considered duly, were not included in calculating the total concentrations of PBBs and PBDEs. Nonparametric methods (Mann- 
Table 1

Statistical results of PBBs (in $\mathrm{ng} \mathrm{g}^{-1}$ lipid) in human tissue samples collected from the e-waste disassembly sites in Zhejiang, China. ${ }^{\mathrm{a}}$

\begin{tabular}{|c|c|c|c|c|c|c|c|c|c|c|c|c|}
\hline \multirow[t]{2}{*}{ Pollutant } & \multicolumn{4}{|c|}{ Kidney $(n=19)$} & \multicolumn{4}{|c|}{ Liver $(n=55)$} & \multicolumn{4}{|c|}{ Lung $(n=7)$} \\
\hline & G.M. & Median & Range & $>$ LOD, \% & G.M. & Median & Range & $>$ LOD, \% & G.M. & Median & Range & $>$ LOD, \% \\
\hline PBB1 & N.A. & N.A. & $0.08-3.58$ & 15.8 & N.A. & N.A. & $0.08-34.64$ & 12.7 & N.A. & N.A. & $0.08-10.47$ & 14.3 \\
\hline PBB2 & 54.49 & 62.73 & $17.28-284.60$ & 100 & 44.73 & 46.46 & $4.12-301.39$ & 100 & 27.51 & 32.00 & $12.65-56.38$ & 100 \\
\hline РBB3 & N.D. & N.D. & N.D. & 0 & N.A. & N.A. & $0.08-47.25$ & 1.8 & N.A. & N.A. & $0.08-11.20$ & 14.3 \\
\hline PBB10 & 0.58 & 0.44 & $0.08-29.72$ & 73.7 & 1.00 & 0.89 & $0.08-34.17$ & 100 & 1.29 & 0.91 & $0.16-39.24$ & 100 \\
\hline PBB4 & N.D. & N.D. & N.D. & 0 & N.D. & N.D. & N.D. & 0 & N.D. & N.D. & N.D. & 0 \\
\hline PBB9 & N.D. & N.D. & N.D. & 0 & N.D. & N.D. & N.D. & 0 & N.D. & N.D. & N.D. & 0 \\
\hline PBB7 & N.D. & N.D. & N.D. & 0 & N.D. & N.D. & N.D. & 0 & N.D. & N.D. & N.D. & 0 \\
\hline PBB15 & 11.28 & 25.79 & $0.10-140.77$ & 78.9 & 9.39 & 24.00 & $0.10-71.93$ & 81.8 & 12.97 & 25.44 & $0.10-71.24$ & 85.7 \\
\hline РВB30 & 2.40 & 7.72 & $0.10-119.23$ & 63.2 & 3.34 & 7.61 & $0.10-81.71$ & 70.9 & 9.08 & 14.55 & $0.10-58.29$ & 85.7 \\
\hline PBB18 & N.A. & N.A. & $0.10-40.56$ & 36.8 & 1.44 & 4.61 & $0.10-38.61$ & 56.4 & 1.78 & 7.27 & $0.10-59.05$ & 57.1 \\
\hline PBB29 & N.A. & N.A. & $0.12-146.15$ & 36.8 & 2.40 & 9.59 & $0.12-79.04$ & 56.4 & 2.93 & 15.93 & $0.12-69.71$ & 57.1 \\
\hline PBB26 & N.A. & N.A. & $0.12-29.43$ & 36.8 & N.A. & N.A. & $0.12-51.64$ & 45.5 & N.A. & N.A. & $0.12-26.00$ & 14.3 \\
\hline РBB31 & N.D. & N.D. & N.D. & 0 & N.A. & N.A. & $0.12-18.43$ & 1.8 & N.D. & N.D. & N.D. & 0 \\
\hline PBB53 & N.A. & N.A. & $0.15-40.00$ & 31.6 & N.A. & N.A. & $0.15-45.97$ & 30.9 & N.A. & N.A. & $0.15-13.94$ & 14.3 \\
\hline РBB38 & N.A. & N.A. & $0.15-64.72$ & 15.8 & N.A. & N.A. & $0.15-69.20$ & 18.2 & N.A. & N.A. & $0.15-17.84$ & 14.3 \\
\hline PBB52 & N.A. & N.A. & $0.15-218.46$ & 31.6 & N.A. & N.A. & $0.15-48.66$ & 21.8 & N.A. & N.A. & $0.15-68.19$ & 14.3 \\
\hline РBB49 & N.D. & N.D. & N.D. & 0 & N.D. & N.D. & N.D. & 0 & N.D. & N.D. & N.D. & 0 \\
\hline PBB103 & N.D. & N.D. & N.D. & 0 & N.D. & N.D. & N.D. & 0 & N.D. & N.D. & N.D. & 0 \\
\hline PBB80 & 3.66 & 32.04 & $0.18-164.62$ & 52.6 & 5.27 & 19.28 & $0.18-91.84$ & 63.6 & 9.24 & 33.02 & $0.18-97.00$ & 71.4 \\
\hline PBB101 & N.A. & N.A. & $0.24-7.73$ & 5.3 & N.A. & N.A. & $0.24-9.33$ & 5.5 & N.A. & N.A. & $0.32-33.45$ & 14.3 \\
\hline PBB155 & N.A. & N.A. & $0.32-33.85$ & 15.8 & N.A. & N.A. & $0.32-33.91$ & 14.5 & N.A. & N.A. & $0.32-88.76$ & 28.6 \\
\hline PBB153 & 9.97 & 29.87 & $0.32-183.85$ & 52.6 & 15.62 & 23.09 & $0.32-97.55$ & 87.3 & 20.15 & 37.96 & $0.32-81.52$ & 85.7 \\
\hline PBBs & 185.81 & 193.87 & $38.86-1137.69$ & 100 & 180.59 & 193.17 & $41.90-558.57$ & 100 & 191.84 & 149.78 & $102.40-676.57$ & 100 \\
\hline PBB209 & N.D. & N.D. & N.D. & 0 & N.D. & N.D. & N.D. & 0 & N.D. & N.D. & N.D. & 0 \\
\hline
\end{tabular}

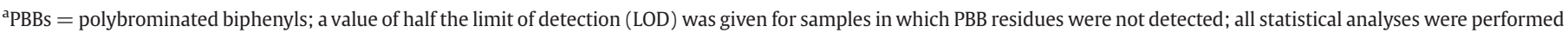
for congeners for which more than $50 \%$ of the samples were above the LOD; G.M.: geometric mean; N.A.: not available; N.D.: not detected; >LOD\%: percent detected.

Whitney U test) was used to determine differences in PHAHs levels among the three types of tissue samples, all statistical significance was set at alpha $=0.05$.

\section{Results}

\subsection{Levels of PBBs measured in the samples}

The levels of the 23 PBB congeners measured in the kidney, liver and lung tissue samples are summarized in Table 1. These data showed that there was a comparable PBBs level among these collected kidney (185.8 $\mathrm{ng} \mathrm{g}^{-1}$ lipid), liver (180.6 $\mathrm{ng} \mathrm{g}^{-1}$ lipid) and lung tissue samples (191.8 $\mathrm{ng} \mathrm{g}^{-1}$ lipid) $(P>0.05)$. Low-brominated PBBs (including PBB2, 10,15 , and 30 ) were found as the most predominant pollutants, accounting for $>59 \%$ of the total PBBs observed; they were detected in more than $50 \%$ of these tissue samples. In addition, hexa-brominated congener PBB153 was also found to be one of the predominant pollutants, which accounted for $>12 \%$ of the total PBBs observed. The
PBB209 levels in all tissue samples were below LOD $\left(<0.80 \mathrm{ng} \mathrm{g}^{-1}\right.$ lipid).

\subsection{Levels of PBDEs measured in the samples}

The levels of the 12 PBDE congeners measured in the three types of tissue samples are summarized in Table 2, which shows that there was a comparable PBDEs level among these collected kidney (182.3 $\mathrm{ng} \mathrm{g}^{-1}$ lipid), liver (174.1 $\mathrm{ng} \mathrm{g}^{-1}$ lipid) and lung tissue samples (174.2 $\mathrm{ng} \mathrm{g}^{-1}$ lipid) $(P>0.05)$. The data in this table also showed that PBDE47 and 28 were the most predominant congeners, accounting for $>17 \%$ and $>10 \%$ of the total PBDEs observed in the collected samples, respectively. For PBDE209, its highest levels observed in kidney, liver, and lung was separately $72,964.5,61,624.7$, and $38,887.6 \mathrm{ng} \mathrm{g}^{-1}$ lipid, which were far higher than those of the other 11 PBDE congeners combined in the corresponding samples; and PBDE209 were detected in more than $70 \%$ of the collected samples.

Table 2

Statistical results of PBDEs (in $\mathrm{ng} \mathrm{g}^{-1}$ lipid) in human tissue samples collected from the e-waste disassembly sites in Zhejiang, China. ${ }^{\mathrm{a}}$

\begin{tabular}{|c|c|c|c|c|c|c|c|c|c|c|c|c|}
\hline \multirow[t]{2}{*}{ Pollutant } & \multicolumn{4}{|c|}{ Kidney $(n=19)$} & \multicolumn{4}{|c|}{ Liver $(n=55)$} & \multicolumn{4}{|c|}{ Lung $(n=7)$} \\
\hline & $\overline{\text { G.M. }}$ & Median & Range & $>\mathrm{LOD}, \%$ & $\overline{\text { G.M. }}$ & Median & Range & $>\mathrm{LOD}, \%$ & G.M. & Median & Range & $>$ LOD, \% \\
\hline PBDE3 & N.D. & N.D. & N.D. & 0 & N.D. & N.D. & N.D. & 0 & N.D. & N.D. & N.D. & 0 \\
\hline PBDE15 & N.D. & N.D. & N.D. & 0 & N.D. & N.D. & N.D. & 0 & N.D. & N.D. & N.D. & 0 \\
\hline PBDE17 & 4.92 & 17.21 & $0.10-75.40$ & 68.4 & 5.14 & 15.47 & $0.10-94.57$ & 69.1 & N.A. & N.A. & $0.10-45.94$ & 42.9 \\
\hline PBDE28 & 29.64 & 48.39 & $0.20-80.00$ & 94.7 & 17.44 & 35.23 & $0.20-102.04$ & 85.5 & 38.50 & 36.96 & $12.80-82.67$ & 100 \\
\hline PBDE47 & 32.36 & 53.56 & $0.20-80.56$ & 94.7 & 36.51 & 50.83 & $0.20-108.16$ & 98.2 & 19.73 & 38.69 & $0.20-73.75$ & 85.7 \\
\hline PBDE66 & N.A. & N.A. & $0.20-60.67$ & 5.3 & N.D. & N.D. & $0.20-91.94$ & 30.9 & N.D. & N.D. & N.D. & 0 \\
\hline PBDE100 & 1.79 & 3.12 & $0.25-91.67$ & 63.2 & 3.37 & 4.97 & $0.25-82.03$ & 81.8 & 3.48 & 6.57 & $0.25-106.67$ & 57.1 \\
\hline PBDE99 & 9.23 & 16.42 & $0.25-26.24$ & 89.5 & 3.89 & 8.65 & $0.25-25.46$ & 72.7 & 4.45 & 12.33 & $0.25-24.35$ & 71.4 \\
\hline PBDE154 & 4.45 & 17.02 & $0.30-238.46$ & 52.6 & 5.85 & 17.39 & $0.30-124.08$ & 60 & 13.40 & 39.48 & $0.30-117.33$ & 71.4 \\
\hline PBDE153 & 4.35 & 15.80 & $0.30-101.94$ & 52.6 & 5.36 & 19.13 & $0.30-111.92$ & 58.2 & 3.31 & 6.75 & $0.30-17.80$ & 71.4 \\
\hline PBDE183 & 2.30 & 4.46 & $0.32-81.61$ & 63.2 & 5.33 & 9.17 & $0.32-20.93$ & 89.1 & 3.22 & 6.77 & $0.32-12.05$ & 71.4 \\
\hline$\Sigma$ PBDEs & 182.33 & 186.09 & $56.49-410.61$ & 100 & 174.10 & 192.61 & $47.69-541.10$ & 100 & 174.23 & 171.96 & $64.42-333.70$ & 100 \\
\hline PBDE209 & 113.85 & 191.27 & $1.00-72964.52$ & 73.7 & 64.16 & 118.10 & $1.00-61624.65$ & 74.5 & 105.07 & 270.00 & $1.00-38887.60$ & 71.4 \\
\hline
\end{tabular}

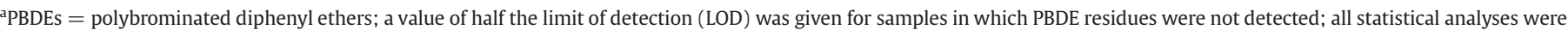
performed for congeners for which more than 50\% of the samples were above the LOD; G.M.: geometric mean; N.A.: not available; N.D.: not detected; >LOD\%: percent detected. 
Table 3

Statistical results of PCBs (in ng $\mathrm{g}^{-1}$ lipid) in human tissue samples collected from the e-waste disassembly sites in Zhejiang, China. ${ }^{\text {a }}$

\begin{tabular}{|c|c|c|c|c|c|c|c|c|c|c|c|c|}
\hline \multirow[t]{2}{*}{ Pollutant } & \multicolumn{4}{|c|}{ Kidney $(\mathrm{n}=19)$} & \multicolumn{4}{|c|}{ Liver $(n=55)$} & \multicolumn{4}{|c|}{ Lung $(n=7)$} \\
\hline & G.M. & Median & Range & $>$ LOD, \% & G.M. & Median & Range & $>$ LOD, \% & G.M. & Median & Range & $>$ LOD, \% \\
\hline PCB8 & 9.29 & 9.24 & $2.61-37.22$ & 100 & 9.79 & 8.67 & $2.05-284.42$ & 100 & 7.23 & 8.76 & $1.73-23.00$ & 100 \\
\hline PCB18 & N.D. & N.D. & N.D. & 0 & N.D. & N.D. & N.D. & 0 & N.D. & N.D. & N.D. & 0 \\
\hline PCB28 & 7.45 & 9.55 & $0.04-35.38$ & 94.7 & 8.21 & 10.64 & $0.04-79.72$ & 96.4 & 9.08 & 10.08 & $3.29-17.02$ & 100 \\
\hline PCB52 & 9.55 & 11.67 & $3.33-36.92$ & 100 & 7.22 & 8.10 & $0.04-46.57$ & 96.4 & 6.68 & 9.87 & $1.21-12.25$ & 100 \\
\hline РСB44 & N.D. & N.D. & N.D. & 0 & N.D. & N.D. & N.D. & 0 & N.D. & N.D. & N.D. & 0 \\
\hline РCB66 & 16.11 & 19.53 & $0.06-69.61$ & 94.7 & 10.66 & 20.46 & 0.06-156.94 & 85.5 & 12.57 & 15.27 & $5.28-23.24$ & 100 \\
\hline PCB101 & 8.78 & 14.82 & $0.07-104.48$ & 89.5 & 11.61 & 15.24 & 0.07-111.07 & 90.9 & 1.94 & 7.71 & $0.07-13.50$ & 71.4 \\
\hline РCB153 & 25.18 & 39.08 & $0.08-224.42$ & 89.5 & 53.50 & 52.43 & $9.59-389.74$ & 100 & 9.31 & 21.30 & $0.08-32.00$ & 85.7 \\
\hline PCB138 & 41.57 & 53.98 & $0.08-223.92$ & 94.7 & 66.87 & 65.12 & $12.35-240.36$ & 100 & 32.58 & 36.95 & $12.90-45.50$ & 100 \\
\hline PCB187 & 4.69 & 8.03 & 0.08-19.39 & 84.2 & 4.30 & 10.67 & $0.08-36.60$ & 80 & 2.00 & 4.59 & $0.08-15.24$ & 71.4 \\
\hline PCB128 & 2.14 & 9.33 & $0.06-53.61$ & 63.2 & 1.19 & 5.10 & $0.06-45.00$ & 56.4 & 5.59 & 12.80 & $0.06-17.45$ & 85.7 \\
\hline PCB180 & 31.32 & 38.06 & $0.08-115.83$ & 94.7 & 49.52 & 53.19 & $10.10-303.55$ & 100 & 4.48 & 21.69 & $0.08-33.00$ & 71.4 \\
\hline РCB170 & 18.25 & 23.25 & $0.08-56.96$ & 94.7 & 21.80 & 25.85 & $0.08-131.25$ & 96.4 & 8.37 & 18.24 & $0.08-31.25$ & 85.7 \\
\hline РCB195 & 13.73 & 18.72 & $0.12-31.39$ & 94.7 & 7.63 & 16.39 & $0.12-45.31$ & 85.5 & 8.14 & 17.37 & $0.12-28.19$ & 85.5 \\
\hline РСВ206 & 13.41 & 20.22 & $0.12-31.03$ & 94.7 & 11.04 & 18.46 & $0.12-42.45$ & 92.7 & 18.38 & 16.73 & $10.74-36.95$ & 92.7 \\
\hline РCB77 & 11.20 & 22.37 & 0.06-36.94 & 89.5 & 7.64 & 16.52 & $0.06-71.92$ & 83.6 & 4.25 & 20.00 & $0.06-38.86$ & 71.4 \\
\hline PCB81 & N.A. & N.A. & $0.06-41.32$ & 10.5 & N.A. & N.A. & $0.06-88.57$ & 10.9 & N.D. & N.D. & N.D. & 0 \\
\hline PCB105 & 1.91 & 13.68 & $0.07-75.47$ & 57.9 & 8.81 & 18.60 & $0.07-79.24$ & 85.5 & N.A. & N.A. & $0.07-16.00$ & 42.9 \\
\hline РCB114 & 6.15 & 20.43 & $0.07-70.06$ & 78.9 & 6.66 & 18.67 & $0.07-73.72$ & 80 & N.A. & N.A. & $0.07-13.94$ & 14.3 \\
\hline РCB118 & N.A. & N.A. & $0.08-25.23$ & 36.8 & N.A. & N.A. & $0.08-27.42$ & 23.6 & N.A. & N.A. & $0.08-16.00$ & 28.6 \\
\hline PCB123 & 21.59 & 34.02 & $0.08-307.85$ & 89.5 & 22.80 & 43.45 & $0.08-199.45$ & 87.3 & 9.15 & 24.00 & $0.08-29.44$ & 85.7 \\
\hline РCB126 & N.D. & N.D. & N.D. & 0 & N.D. & N.D. & N.D. & 0 & N.D. & N.D. & N.D. & 0 \\
\hline РCB156 & N.A. & N.A. & $0.08-44.44$ & 31.6 & N.A. & N.A. & $0.08-595.71$ & 47.3 & N.D. & N.D. & N.D. & 0 \\
\hline PCB157 & N.A. & N.A. & $0.08-11.33$ & 5.3 & N.A. & N.A. & $0.08-13.93$ & 7.3 & N.D. & N.D. & N.D. & 0 \\
\hline PCB167 & N.A. & N.A. & $0.08-10.43$ & 31.6 & N.A. & N.A. & $0.08-17.55$ & 34.5 & N.A. & N.A. & $0.08-9.75$ & 28.6 \\
\hline PCB169 & N.A. & N.A. & $0.08-0.83$ & 5.3 & N.A. & N.A. & $0.08-3.92$ & 3.6 & N.D. & N.D. & N.D. & 0 \\
\hline РCB189 & 2.26 & 7.11 & $0.12-45.96$ & 57.9 & N.A. & N.A. & $0.12-184.68$ & 47.3 & 6.12 & 18.08 & $0.12-180.22$ & 71.4 \\
\hline$\Sigma$ PCBs & 399.35 & 382.15 & $86.92-1403.92$ & 100 & 455.13 & 460.00 & 89.19-1742.57 & 100 & 257.91 & 304.64 & $104.85-373.25$ & 100 \\
\hline ¿TEQs ${ }^{\mathrm{b}}$ & $13.13 \times 10^{-3}$ & $18.98 \times 10^{-3}$ & $(0.01-100) \times 10^{-3}$ & 100 & $16.81 \times 10^{-3}$ & $21.09 \times 10^{-3}$ & $(0.01-328.30) \times 10^{-3}$ & 100 & $7.57 \times 10^{-}$ & $8.22 \times 10^{-3}$ & $(2.23-18.00) \times 10^{-3}$ & 100 \\
\hline
\end{tabular}

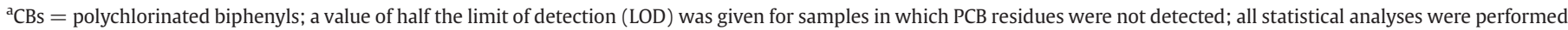

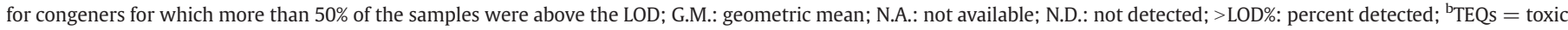

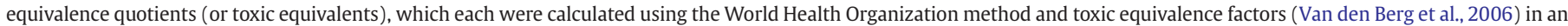
effort to weight the toxicity as well as the potency of dioxin (2.3.7.8-TCDD)-like PCB compounds (i.e., those last 12 PCBs listed in this table) in relation to that of TCDD.

\subsection{Levels of PCBs measured in the samples}

As summarized in Table 3, among the three subfamilies of PHAHs (excluding PBDE209), PCBs had the highest concentrations in these tissue samples collected from these e-waste disassembly sites, with levels ranging from 257.9 to $455.1 \mathrm{ng} \mathrm{g}^{-1}$ lipid. PCB138 was the most predominant congener, detected in more than $85 \%$ of the collected samples. The level $\Sigma_{T E Q_{P C B s}}$ (the sum of the toxic equivalents) observed in kidney, liver, and lung tissue samples was 13.1, 16.8, and $7.6 \mathrm{pg} \mathrm{g}^{-1}$ lipid, respectively.

\section{Discussion}

The PHAHs in the three subfamilies (PBBs, PBDEs and PCBs) were all detectable in the collected tissue samples at high levels, which showed that these PHAHs had entered the patients' body through environment and dietary exposure. The detected levels of PHAHs were in the same order of magnitude in the three tissues, which indicated that any of the three tissues could be the suitable indicator for assessing actual body burden of PHAHs.

\subsection{PBBs in human tissue}

Low-brominated PBBs were the principal congeners in the e-waste residues, surface soil, and hair samples (Zhao et al., 2008). Results from the last study well supported the assertion that low-brominated PBBs (including PBB2, 10, 15, and 30) were the predominant congeners observed in the human tissue sample, which were seen to have accounted for as much as $59 \%$ of the total PBBs. Some investigations indicated that the high-brominated PBBs may metabolize to their lowbrominated congeners in body. For example, fish (juvenile Salmo salar), exposed in laboratory studies to FireMaster ${ }^{(\mathrm{R})} \mathrm{BP}-6$ in water, contained several mono to penta-bromobiphenyls that were not present in BP-6 (Zitko, 1977;WHO, 1994a; Stapleton et al., 2004).

The commercial production of PBBs began in the 1970s. Approximately 6 million $\mathrm{kg}$ of PBBs were produced in the United States from 1970 to 1976, hexabromobiphenyl constituted about 5.4 million $\mathrm{kg}$ (88\%) of this total (Neufeld et al., 1977). The congener PBB153 was the principal component in commercial hexabromobiphenyl, which accounts for $60-80 \%$ of the total weight (POPRC, 2007a). Hexabromobiphenyl was widely used as a fire retardant in three main commercial products: acrylonitrile- butadiene-styrene (ABS) thermoplastics for constructing business machine housings and in industrial (e.g. motor housing), and electrical (e. g. radio and TV parts) products; as a fire retardant in coatings and lacquers; and in polyurethane foam for auto upholstery (WHO, 1994a; POPRC, 2007a). Most in the production of plastic products with an estimated use life of 5-10 years (Neufeld et al., 1977), since the cessation of production, all of these products, such as TV cabinet and business machine housings, must have been disposed of in the e-waste disassembly sites or incineration (Neufeld et al., 1977; US ATSDR, 2004). Therefore, PBB153 were deemed likely present in humans living around the e-waste disassembly sites. The results of this study showed that PBB153 was also a predominant congener, which accounted for $12 \%$ the total PBBs observed. Obviously, the content was far lower than $60-80 \%$, which is the percent of PBB153 in this commercial production of PBBs. Large part of PBBs was produced and used in the 1970s (WHO, 1994a; POPRC, 2007a). The metabolization rate of hexa-PBBs was faster than hexa-PCBs (WHO, 1994a), and during the $30-40$ year period after these compounds were produced, they might have been metabolized to low-brominated PBBs. In addition, these factors, such as photolytic degradation, microbial degradation, and degradation by plants and 
animals, can lead to PBB153 decrease. PBB209 was not be detected in the collected tissue samples, this finding is consistent with the fact that no PBB209 was observed in the sampled food in our earlier study.

\subsection{PBDEs in human tissue}

PBDE47 was the most predominant PBDE congener, accounting for $>17 \%$ of the total PBDEs observed in the collected samples. Many researchers also found similar results in human milk and blood samples (Meironyté Guvenius et al., 2001; Covaci et al., 2008). PBDE47 was reported to be one of the main isomers in commercial pentaBDE product, and the congener was also found to be the primary PBDE congener in the food samples in our earlier study, these facts supported well the above-mentioned finding in the study.

PBDE28 was found to be one of the most abundant PBDE congeners in air particles from another electronic waste recycling site (Guiyu) (Deng et al., 2007), and was also detected at a high level in the e-waste residues, soil and food samples collected from the disassembly sites in

Table 4

Levels of PBBs, PBDEs, and PCBs (in ng g lipid ${ }^{-1}$ ) among human tissues in various localities in China and other countries.

\begin{tabular}{|c|c|c|c|c|c|c|c|c|}
\hline Countries (or districts) & $\mathrm{N}$ & Sampling year & Characteristics of the study & PBBs & PBDEs & PCBs & PBDE209 & References \\
\hline Belgium $^{\mathrm{a}}$ & 20 & 2000 & Adipose & - & $2.2-11.7$ & $841(286-1802)$ & - & Covaci et al. (2002) \\
\hline Belgium ${ }^{\mathrm{b}}$ & 25 & 2003-2005 & Liver & - & $3.6(1-10)$ & $380(90-1140)$ & - & Covaci et al. (2008) \\
\hline Belgium $^{\mathrm{b}}$ & 25 & 2003-2005 & Adipose & - & $5.3(1.4-13.2)$ & $490(70-1130)$ & - & Covaci et al. (2008) \\
\hline Belgium $^{c}$ & 53 & 2001-2003 & Adipose & - & $11.1(1.2-57.2)$ & 763.7 (126-2090) & - & Naert et al. (2006) \\
\hline China (Shanghai) ${ }^{\mathrm{d}}$ & 5 & 2001 & Mammary glands & - & - & $70(27-135)$ & - & Nakata et al. (2002) \\
\hline China (Taiwan) ${ }^{\mathrm{e}}$ & 20 & 2000-2001 & Human milk & - & 3.9 & - & 0.3 & Chao et al. (2007) \\
\hline China (Guiyu) $)^{f}$ & 26 & 2005 & Serum & - & $580(140-8500)$ & $69(17-180)$ & 340 & Bi et al. (2007) \\
\hline China (Haojiang) ${ }^{\mathrm{f}}$ & 21 & 2005 & Serum & - & $190(16-490)$ & $65(22-140)$ & 130 & Bi et al. (2007) \\
\hline China (Guangdong) ${ }^{g}$ & 20 & 2006 & Serum & - & - & - & 3436 & Qu et al. (2007) \\
\hline China (Wenling) & 19 & 2008 & Kidney & 185.8 & 182.3 & 399.4 & 113.9 & Present study \\
\hline China (Wenling) & 55 & 2008 & Liver & 180.6 & 174.1 & 455.1 & 64.2 & \\
\hline China (Wenling) & 7 & 2008 & Lung & 191.8 & 174.2 & 257.9 & 105.1 & \\
\hline Denmark $^{\mathrm{h}}$ & 409 & 1993-1997 & Case Adipose & - & - & 1027.4 & - & Raaschou-Nielsen et al. (2005) \\
\hline Denmark $^{\mathrm{h}}$ & 409 & 1993-1997 & Control Adipose & - & - & 1924.9 & - & Raaschou-Nielsen et al. (2005) \\
\hline Germany $^{\mathrm{i}}$ & 25 & - & Human milk & 2 & - & - & - & WHO (1994a) \\
\hline Japan $^{\mathrm{j}}$ & 12 & 2002 & Human milk & - & $0.7-2.8$ & - & - & Ohta et al. (2002) \\
\hline $\mathrm{Japan}^{\mathrm{k}}$ & 89 & 2005 & Human milk & - & 1.6 & 63.9 & 0.6 & Inoue et al. (2006) \\
\hline $\operatorname{Japan}^{\mathrm{k}}$ & 89 & 2005 & Serum & - & 2.9 & 37.5 & 0.3 & Inoue et al. (2006) \\
\hline Singapore $^{1}$ & 16 & 2003-2004 & Adipose & - & $0.5-12.3$ & - & - & Li et al. (2005) \\
\hline Spain $^{\mathrm{m}}$ & 20 & 2003 & Adipose & 0.4 & 3.9 & - & - & Fernandez et al. (2007) \\
\hline Sweden $(\text { Stockholm })^{\mathrm{n}}$ & 5 & 1994 & Liver & - & $4.5-18$ & 459-2085 & - & Meironyté Guvenius et al. (2001) \\
\hline Sweden $(\text { Stockholm })^{\mathrm{n}}$ & 5 & 1994 & Adipose & - & $3.8-7.7$ & $561-2343$ & - & Meironyté Guvenius et al. (2001) \\
\hline Sweden ${ }^{\circ}$ & 21 & 1996-1999 & Adipose & - & 2.3 & 757 & - & Hardell et al. (2007) \\
\hline Sweden $^{\circ}$ & 59 & 1996-1999 & Adipose & - & 5.1 & 1687 & - & Hardell et al. (2007) \\
\hline Sweden $^{\mathrm{p}}$ & 7 & 2000 & Serum & - & - & - & 270 & Thuresson et al. (2005) \\
\hline $\mathrm{UK}^{\mathrm{q}}$ & 154 & 2003 & Serum & - & $5.6(0.6-420)$ & $170(14-670)$ & $15-240$ & Thomas et al. (2006) \\
\hline US (Michigan) ${ }^{\mathrm{r}}$ & 64 & 1975-1994 & Serum $(\leq 10 \mathrm{y})$ & $10,456.2$ & - & $1,998.0$ & - & Sweeney et al. (2001) \\
\hline US (Michigan) ${ }^{r}$ & 149 & 1975-1994 & Serum (11-16 y) & 6660.0 & - & 1931.4 & - & Sweeney et al. (2001) \\
\hline US (Michigan) ${ }^{r}$ & 347 & 1975-1994 & Serum (17-42 y) & 3429.2 & - & 2264.4 & - & Sweeney et al. (2001) \\
\hline US (Michigan) ${ }^{\mathrm{s}}$ & 196 & 1985 & Adipose & 475 & - & - & - & Miceli et al. (1985) \\
\hline$U^{t}$ & 9 & 1985-1989 & Serum & $8.0(2.6-9.4)$ & $9.6(4.6-74)$ & $90(48-140)$ & - & Sjödin et al. (2004) \\
\hline$U^{t}$ & 14 & 1990-1994 & Serum & $5.3(1.0-8.6)$ & $48(7.5-86)$ & $66(38-87)$ & - & Sjödin et al. (2004) \\
\hline$U^{t}$ & 10 & 1995-1999 & Serum & $4.7(1.9-10)$ & $71(42-120)$ & $52(36-110)$ & - & Sjödin et al. (2004) \\
\hline$U^{t}$ & 7 & 2000-2002 & Serum & $3.3(1.4-5.5)$ & $61(47-160)$ & $35(19-49)$ & - & Sjödin et al. (2004) \\
\hline US (Texas) ${ }^{\mathrm{u}}$ & 47 & 2002 & Human milk & - & $73.9(6.2-419)$ & - & $0.9(\mathrm{ND}-8.2)$ & Schecter et al. (2003) \\
\hline US (California) ${ }^{\mathrm{V}}$ & 21 & 2003 & Adipose & - & $91(17-440)$ & 404 & - & Petreas et al. (2004) \\
\hline US (New York) ${ }^{\mathrm{w}}$ & 52 & 2003-2004 & Adipose & - & $399(17-9630)$ & $144(18.9-816)$ & - & Johnson-Restrepo et al. (2005) \\
\hline US (Texas) $)^{\mathrm{u}}$ & 11 & 2007 & liver & - & $23.1(4-98)$ & - & - & Schecter et al. (2007) \\
\hline
\end{tabular}

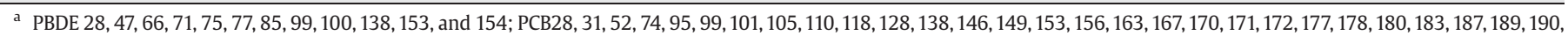
$194,195,196 / 203,199,206$, and 209.

b PBDE28, 47, 99, 100, 153, 154 and 183; PCB28/31, 52, 74, 95, 99, 101, 105, 110, 118, 128, 138/163, 149, 153, 156, 170, 180, 183, 187, 194, and 196.

c PBDE28, 47, 99, 100, 154, 153, and 183; PCBs 28, 52, 101, 118, 138, 153, and 180.

d Kanechlor mixture (KC-300, 400, 500, and 600).

e PBDE17, 28, 47, 66, 85, 99, 100, 138, 153, 154, 183, and 209.

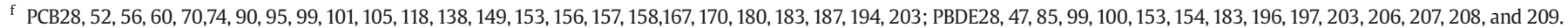

$\mathrm{g}$ The highest concentration of PBDE209 was observed in serum of the electronic waste dismantling workers $3436 \mathrm{ng}^{\mathrm{g}}$ lipid ${ }^{-1}$.

h PCB28, 52, 54, 55, 99, 101, 104, 105, 118, 128, 138, 153, 156, 170, 180, 183, 187, and 201.

i PBB103, 131, 132, 135, 147, 148, 149, 153, 154, 155, 169, 176, 178, 179, 180, 181, 184, 185, 186, 187, 188, 192, 194, 197, 198, $200,201$.

j PBDE28, 47, 99, 100, 153, and 154.

k PBDE 15, 28, 47, 99, 100, 153, 154, 183, 196, 197, 206, 207, and 209; PCB74, 99, 118, 138, 146, 153, 156, 163/164, 170, 180, 182/187, 194, 199, 206, and 209.

${ }^{1}$ PBDE47, 99, 100, 153, and 154.

m PBB18, 29, 31, 22, 38, 37, 53, 52, 49, 75, 80, 56, 77, 103, 101, 155, 154, 153, and 169; PBDE 28, 75, 71, 47, 66, 77, 100, 119, 99, 85, 154, 153,138 , and 183.

n PBDE17, 28, 47, 66, 85, 99, 100, 153, and 154; PCB28, 47, 52, 101, 105, 114, 118, 122, 123, 138, 153, 156, 157, 167, 170, 180, and 189.

o PCB28, 74, 101, 105, 114, 118, 128, 138, 149, 153, 156, 170, 180, and 187.

p The highest PBDE209 concentration observed in serum of the rubber workers was $270 \mathrm{ng} \mathrm{g} \mathrm{lipid}^{-1}$.

q PBDE17, 28, 32, 35, 37, 47, 49, 71, 75, 77, 85, 99, 100, 119, 138, 153, 154, 166, 181, 183 and 190; PCBs 18, 22, 28, 31, 41/64, 44, 49, 52, 54, 70, 74, 87, 90/101, 95, 99, 104, 105, 110, 114, 118, $123,138,141,149,151,153,155,156,157,158,167,170,174,180,183,187,188,189,194,199$ and 203.

r Aroclor 1254

s Hexabromobiphenyls.

t PBB153; PBDE47, 85, 99, 100, 153, and 154; PCB153.

u PBDE17, 28, 47, 66, 77, 85, 99, 100, 138, 153, 154, 183, and 209.

v PBDE47, 99, 100, 153, and 154; PCB118, 138, 153, and 180.

w PBDE28, 30, 47, 85, 99, 100, 153, and 154; Kanechlor (KC 300, 400, 500, and 600). 
our earlier study (Zhao et al., 2008). The congener thus can enter the body through three main routes of exposure: inhalation, ingestion and skin penetration. In addition, the metabolism of high brominated congeners to lower brominated ones could also contribute to the high proportion of PBDE28 in samples observed.

PBDE209 has low bioaccumulative potential, and low biologic activity (Hooper and McDonald, 2000). Additionally, PBDE209 may break down in sunlight or anaerobic degradation into the lowbrominated PBDE congeners (Watanabe and Tatsukawa, 1978). PBDE209 was not thus considered to be bioavailable (Kierkegaard et al., 1999), which contrasted with the result on high concentration of PBDE209 which was found in the collected human tissue samples, especially, the highest concentration of PBDE209 was detected in kidney tissue samples (72,964.5 $\mathrm{ng} \mathrm{g}^{-1}$ lipid). Bi et al. (2007) and Thuresson et al. (2005) also observed high concentrations of PBDE209 in serum from electronics dismantlers ( $340 \mathrm{ng} \mathrm{g}^{-1}$ lipid) and rubber workers (300 $\mathrm{pmol} \mathrm{g}^{-1}$ lipid) manufacturing or handling rubber compound that was flame retarded with a technical mixture of PBDE209. These findings evidently indicated that PBDE209 was bioavailable.

Sandholm (2003) observed a short half-life $\left(t_{1 / 2}=2.4\right.$ days) for PBDE209 in rats dosed with this congener. Also, gray seals experimentally dosed with PBDE209 indicated a short half-life (8-13 days) of this compound (Thomas et al., 2006). Observations in five electronic dismantlers sampled before and after 30 days of vacation suggested a rather rapid elimination of PBDE209, with a median decrease of $66 \%$ during this period of time (Sjödin et al., 1999). The half-life of PBDE209 is so short, yet the compound still can be found at a high level in the human tissue samples in the present study. The finding suggested that there might be new inputs of the congener. In fact, PBDE209 is the most widely used PBDEs, which accounts for more than $70 \%$ of the total PBDE demand, with a global demand of about 56,100 tonnes in 2001 and 56,418 tonnes in 2003 (US ATSDR, 2004; POPRC, 2007b). PBDE209 is used in ABS-plastics, high impact polystyrene, epoxy resins, and rubber, and thus may appear in such ewaste products as obsolete or end-of-life printed circuit boards, cables, and television sets (POPRC, 2007b). Therefore, under ideal conditions it would be more readily released into the environment. These disassembly workers might be exposed to PBDE209 by breathing contaminated workplace air and by skin contact (WHO, 1994b). Residents who live near e-waste disassembly sites may be exposed primarily by breathing air and ingesting food. In addition, PBDE209 are still manufactured and used in China. Therefore, these facts all supported the observation that PBDE209 was the predominant congener measured in the collected human tissue samples.

\subsection{PCBs in human tissue}

Among the three subfamilies of PHAHs (excluding PBDE209), PCBs had the highest concentrations in the human tissue samples, this finding was consistent with highest PCB intake (12,372.9 $\mathrm{ng} \mathrm{day}^{-1}$ ) observed in the daily dietary estimation for residents living around the e-waste disassembly sites in the earlier study. The most predominant $\mathrm{PCB}$ congener in these samples was $\mathrm{PCB} 138$, with its concentrations accounting for $10 \%$ of the total $\mathrm{PCBs}$ concentrations observed, similar findings for the congener were also observed in the soil, food, cord blood, and milk samples from the disassembly sites (Zhao et al., 2007a,b).

Covaci et al. (2008) found that PCBs were significantly correlated with age, but no correlation was observed between PBDEs and age. There is no correlation between levels of PBDEs (or PCBs) and age in the present study. As mentioned above, e-waste is the pollution source for the local environment, therefore, the type and amount of e-waste can directly result in different types of PHAHs pollution (e.g., the primary pollutants in obsolete transformers are PCBs), which will change the type and amount of PHAHs observed in the residents, additionally, the distance from the e-waste disassembly sites to the living sites of residents may also change the level of exposure for residents to PHAHs, these factors influence the observed values of these PHAHs in tissues of residents, which leads to the levels of PHAHs being not only affected by age.

\subsection{International comparison}

To further appreciate the level of contamination in human tissue from the e-waste disassembly sites, the PHAHs levels monitored in the present study were compared to those reported recently for districts located in other Chinese provinces and other countries. As shown in Table 4, the concentrations of PBBs in kidney, liver and lung tissue samples (ranging from 181-192 $\mathrm{ng} \mathrm{g}^{-1}$ lipid) were ten times of those reported in the general USA population (3-8 $\mathrm{ng} \mathrm{g}^{-1}$ lipid), however, the observed value were still far lower than the means (ranging from 3,429 to $10,456.2 \mathrm{ng} \mathrm{g}^{-1}$ lipid) observed in the Michigan study, in which a widespread contamination of farm products by PBBs occurred. PBDE levels observed were comparable to those reported in the general USA population, which were also significantly higher than those reported values in European population. PCBs level was in the same order of magnitude as those reported on population in European industrialized country.

This investigation is the first that reports in detail the recent levels of PBBs, PBDEs and PCBs in human tissue samples from areas near the disassembly sites for e-waste in Zhejiang Province. The data from this preliminary study show that high PHAH levels were detected in the cancer patients' tissue samples, thus suggesting that the higher cancer incidence in the e-waste disassembly ßsites may be related to higher burdens of PBBs, PBDEs, and PCBs. However, more in-depth investigation of such an association is needed.

\section{Acknowledgements}

This study was supported by the National Key Technology R\&D Program (2007BAC27B02), National Basic Research Program of China (2006CB403400), National Nature Science Foundation (20737003 and 50721006) and SKLEAC (52TS200801).

\section{References}

Bi X, Thomas G, Jones K, Qu W, Sheng G, Martin F, et al. Exposure of electronics dismantling workers to polybrominated diphenyl ethers, polychlorinated biphenyls and organochlorine pesticides in south China. Environ Sci Technol 2007;41:5647-53.

Chao H, Wang S, Lee W, Wang Y, Päpke O. Levels of polybrominated diphenyl ethers (PBDEs) in breast milk from central Taiwan and their relation to infant birth outcome and maternal menstruation effects. Environ Int 2007;33:239-45.

Covaci A, de Boer J, Ryan J, Voorspoels S, Schepens P. Distribution of organobrominated and organochlorinated contaminants in Belgian human adipose tissue. Environ Res 2002;88:210-8

Covaci A, Voorspoels S, Roosens L, Jacobs W, Blust R. Polybrominated diphenyl ethers (PBDEs) and polychlorinated biphenyls (PCBs) in human liver and adipose tissue samples from Belgium. Chemosphere 2008;73(2):170-5.

Deng J, Zheng J, Bi X, Fu J, Wong M. Distribution of PBDEs in air particles from an electronic waste recycling site compared with Guangzhou and Hong Kong, South China. Environ Int 2007;33:1063-9.

Fernandez M, Araque P, Kiviranta H, Molina-Molina J, Rantakokko P, Laine O, et al. PBDEs and PBBs in the adipose tissue of women from Spain. Chemosphere 2007;66:377-83.

Hardell L, Carlberg M, Hardell K, Björnfoth H, Wickbom G, Ionescu M, et al. Decreased survival in pancreatic cancer patients with high concentrations of organochlorines in adipose tissue. Biomed Pharmacother 2007;61:659-64.

Hardy M. In: de Boer J, Leonard P, Boon J, Law R, editors. Results presented at BSEF workshop on polybrominated diphenyl ethers. The Netherlands: The Netherlands Institute for Fisheries Research (RIVO); 2000.

Hicks C, Dietmar R, Eugster M. The recycling and disposal of electrical and electronic waste in China-legislative and market responses. Environ Impact Assess Rev 2005;25:459-71.

Hooper K, McDonald T. The PBDEs: an emerging environmental challenge and another reason for breast-milk monitoring programs. Environ Health Perspect 2000;108: 387-92.

Inoue K, Harada K, Takenaka K, Uehara S, Kono M, Shimizu T, et al. Levels and concentration ratios of polychlorinated biphenyls and polybrominated diphenyl ethers in serum and breast milk in Japanese mothers. Environ Health Perspect 2006;114:1179-85. 
Johnson-Restrepo B, Kannan K, Rapaport D, Rodan B. Polybrominated diphenyl ethers and polychlorinated biphenyls in human adipose tissue from New York. Environ Sci Technol 2005;39:5177-82.

Kierkegaard A, Balk L, Tjärnlund U, de Wit C, Jansson B. Dietary uptake and biologica effects of decabromodiphenyl ether in rainbow trout (Oncorhynchus mykiss). Environ Sci Technol 1999;33:1612-7.

Li Q Loganath A, Chong Y, Obbard J. Determination and occurrence of polybrominated diphenyl ethers in maternal adipose tissue from inhabitants of Singapore. J Chromatogr B 2005;819:253-7.

Liu H, Zhang Q Cai Z, Li A, Wang Y, Jiang G. Separation of polybrominated diphenyl ethers, polychlorinated biphenyls, polychlorinated dibenzo-p-dioxins and dibenzo- furans in environmental samples using silica gel and florisil fractionation chromatography. Anal Chim Acta 2006;557:314-20.

Luo Q, Cai Z, Wong M. Polybrominated diphenyl ethers in fish and sediment from river polluted by electronic waste. Sci Total Environ 2007;383:115-27.

McDonald T. A perspective on the potential health risks of PBDEs. Chemosphere 2002;46:745-55.

Meironyté Guvenius D, Bergman Å, Norén K. Polybrominated diphenyl ethers in Swedish human liver and adipose tissue. Arch Environ Contam Toxicol 2001;40: 564-70.

Miceli J, Nolan D, Marks B, Hariharan M. Persistence of polybrominated biphenyls (PBB) in human post-mortem tissue. Environ Health Perspect 1985;60:399-403.

Naert C, Piette M, Bruneel N, Van Petegheml C. Occurrence of polychlorinated biphenyls and polybrominated diphenyl ethers in Belgian human adipose tissue samples. Arch Environ Contam Toxicol 2006;50:290-6.

Nakata H, Kawazoe M, Arizono K, Abe S, Kitano T, Shimada H, et al. Organochlorine pesticides and polychlorinated biphenyl residues in foodstuffs and human tissues from China: status of contamination, historical trend, and human dietary exposure. Arch Environ Contam Toxicol 2002;43:473-80.

Neufeld M, Sittenfield M, Wolk K. Market input/output studies: Task IV. Polybrominated biphenyls; 1977. Washington, DC. US EPA, EPA-560677017.

Ohta S, Ishizuka D, Nishimura H, Nakao T, Aozasa O, Shimidzu Y, et al. Comparison of polybrominated diphenyl ethers in fish, vegetables, and meats and levels in human milk of nursing women in Japan. Chemosphere 2002;46:689-96.

Persistent Organic Pollutants Review Committee (POPRC). Stockholm convention on persistent organic pollutants. Draft Risk Management Evaluation for Hexabromobiphenyl; 2007a.

Persistent Organic Pollutants Review Committee (POPRC). Stockholm convention on persistent organic pollutants. Draft Risk Management Evaluation for Commercia Pentabromodiphenyl Ether; 2007b.

Petreas M, Smith D, Hurley S, Jeffrey S, Gilliss D, Reynolds P. Distribution of persistent, lipid-soluble chemicals in breast and abdominal adipose tissues: lessons learned from a breast cancer study. Cancer Epidemiol Biomarkers Prev 2004;13:416-23.

Qu W, Bi X, Sheng G, Lu S, Fu J, Yuan J, et al. Exposure to polybrominated diphenyl ethers among workers at an electronic waste dismantling region in Guangdong, China. Environ Int 2007;33:1029-34.

Raaschou-Nielsen O, Pavuk M, LeBlanc A, Dumas P, Weber J, Olsen A, et al. Adipose organochlorine concentrations and risk of breast cancer among postmenopausal Danish women. Cancer Epidemiol Biomarkers Prev 2005;14:67-74.

Sandholm, A. Metabolism of some polychlorinated biphenyl and polybrominated diphenyl ether congeners in the rat, Doctoral thesis, Dep. of environmental chemistry, Stockholms University, Stockholm, 2003.

Schecter A, Pavuk M, Päpke O, Ryan J, Birnbaum L, Rosen R. Polybrominated dipheny ethers (PBDEs) in U.S. mothers' milk. Environ Health Perspect 2003;111:1723-9.
Schecter A, Johnson-Welch S, Tung K, Harris T, Papke O, Rosen R. Polybrominated diphenyl ether (PBDE) levels in livers of U.S. human fetuses and newborns. J Toxicol Environ Health A 2007;70:1-6.

Sjödin A, Hagmar L, Klasson-Wehler E, Kronholm-Diab K, Jakobsson E, Bergman A. Flame retardant exposure: polybrominated diphenyl ether exposure in Swedish workers. Environ Health Perspect 1999;107:643-8.

Sjödin A, Jones R, Focant J, Lapeza C, Wang R, McGahee III E, et al. Retrospective timetrend study of polybrominated diphenyl ether and polybrominated and polychlorinated biphenyl levels in human serum from the United States. Environ Health Perspect 2004;112:654-8.

Stapleton $H$, Alaee $M$, Letcher R, Baker J. Debromination of the flame retardant decabromodiphenyl ether by juvenile carp (Cyprinus carpio). Environ Sci Technol 2004;38:112-9.

Sweeney A, Symanski E, Burau K, Kim Y, Humphrey H, Smith M. Changes in serum PBB and $\mathrm{PCB}$ levels over time among women of varying ages at exposure. Environ Res 2001;86:128-39.

Thomas G, Wilkinson M, Hodson S, Jones K. Organohalogen chemicals in human blood from the United Kingdom. Environ Pollut 2006;141:30-41.

Thuresson K, Bergman A, Jakobsson K. Occupational exposure to commercial decabromodiphenyl ether in workers manufacturing or handling flame-retarded rubber. Environ Sci Technol 2005;39:1980-6.

US Agency for Toxic Substances and Disease Registry (US ATSDR). Toxicological profile for polybrominated biphenyls and polybrominated diphenyl ethers (PBBs and PBDEs), Atlanta, GA; 2004. http://www.atsdr.cdc.gov/toxprofiles/tp68.html.

US Environmental Protection Agency (US EPA). Method 3630C - Silica Gel Cleanup, SW846 Manual (Test Methods for Evaluating Solid Waste, Physical/Chemical Methods) 3rd Ed.; 1996. http://www.epa.gov/epaoswer/hazwaste/test/3_series.htm.

Van den Berg M, Birnbaum L, Denison M, De Vito M, Farland W, Feeley M, et al. The 2005 World Health Organization re-evaluation of human and mammalian toxic equivalency factors for dioxins and dioxin-like compounds. Toxicol Sci 2006;93:223-41.

Wang D, Cai Z, Jiang G, Leung A, Wong M, Wong W. Determination of polybrominated diphenyl ethers in soil and sediment from an electronic waste recycling facility. Chemosphere 2005;60:810-6.

Watanabe I, Tatsukawa R. Formation of brominated dibenzofurans from the photolysis of flame retardant decabromobiphenyl ether in hexane solution by UV and sunlight. Bull Environ Contam Toxicol 1978;39:953-9.

World Health Organization (WHO). Environmental health criteria 152. Polybrominated biphenyls. International Program on Chemical Safety. Geneva, Switzerland: WHO; 1994a. http://www.inchem.org/documents/ehc/ehc/ehc152. htm.

World Health Organization (WHO). Environmental health criteria 162. Brominated diphenylethers. International Program on Chemical Safety. Geneva, Switzerland: WHO; 1994b. http://www.inchem.org/documents/ehc/ehc/ehc192.htm.

Zhao G, Xu Y, Li W, Han G, Ling B. Fetus prenatal exposure to persistent organic pollutants in cord blood and meconium in three different localities of Zhejiang. Sci Total Environ 2007a;377:179-91.

Zhao G, Xu Y, Li W, Han G, Ling B. PCBs and OCPs in human milk and selected food from the disassembly locality for obsolete transformer and non- disassembly locality in Zhejiang, China. Sci Total Environ 2007b;378:281-92.

Zhao G, Wang Z, Dong M, Rao K, Luo J, Wang D, et al. PBBs, PBDEs, and PCBs levels in hair of residents around e-waste disassembly sites in Zhejiang Province, China, and their potential sources. Sci Total Environ 2008;397:46-57.

Zitko V. The accumulation of polybrominated biphenyls by fish. Bull Environ Contam Toxicol 1977; 17:285-92. 